\title{
CONEXÕES DE SENTIDO NA LITERATURA ASHKENAZI DE A PAIXÃO SEGUNDO G.H., DE CLARICE LISPECTOR, NO CONTO “A LINGUAGEM \\ DOS PÁSSAROS” E NO LIVRO AS HISTÓRIAS DO RABI NAKHMAN, DE MARTIN BUBER
}

\author{
Leila Borges Dias Santos ${ }^{1}$
}

\section{Resumo}

A experiência epifânica de A Paixão Segundo G.H. relacionada a lendas hassídicas, como a do conto "A linguagem dos pássaros", do livro A Lenda do Baal Schem Tov e no livro As histórias do Rabi Nakhman, de Martin Buber, atesta a cosmovisão judaica ashkenazi presente nas obras. Contribuições da crítica pertinente e leituras sobre a mística judaica demonstram aproximações entre as mesmas pelo fato de retratarem um cotidiano de encantamento, sacralização e devoção.

\section{Palavras-chave}

Clarice Lispector. A Paixão segundo G.H. Martin Buber. Lendas hassídicas. Rabi Nakhman.

\section{Introdução}

A literatura de Clarice Lispector, em especial em A Paixão segundo G.H., pode ser entendida como uma incursão ao universo do sagrado, um meio de diluição das fronteiras entre o natural e o sobrenatural, sob o véu do cotidiano.

Na referida obra clariceana, a narrativa, a linguagem, a personagem e o espaço literário construídos são marcados pela angústia do indivíduo moderno e por uma condição epifânica, devido a experiências místicas e recorrentes a incursões no sagrado.

Em G.H., os liames da linguagem e da epifania são fundamentais para se acompanhar as respectivas conexões de sentido religioso, no caso, da mística judaica. Seu principal elemento seria o encantamento, ou a contemplação junto aos fenômenos mais simples que podem se transformar em acontecimentos de fascínio e transformação da forma de se ver a realidade, como ocorre no quartinho minúsculo do apartamento da personagem G.H.

Uma vez apresentada a análise sobre G.H., serão feitas possíveis conexões entre a narrativa dessa obra e o universo devocional retratado por Buber, - por exemplo, no conto "O Canto dos pássaros", do livro A lenda do Baal Schem, e em passagens de um outro

\footnotetext{
${ }^{1}$ Doutora em Sociologia pela UnB. Professora do Departamento de Estudos Literários da Faculdade de Letras da Universidade Federal de Goiás - Regional Goiânia. Integrante do Grupo de Pesquisa, Laboratório de Estudos Judaicos (LEJ) - Universidade Federal de Uberlândia.
} 
livro do autor, sobre a vida do Rabino Nakhman, bisneto do Baal Schem, chamado As histórias do Rabi Nakhman, - e seu respectivo pano de fundo cultural, o da cultura hassídica, elemento amalgamador da origem cultural e religiosa de ambos os autores, com ênfase na obra da escritora naturalizada brasileira, o que será demonstrado no decorrer do texto, devido à maior parte dele ser dedicada à análise de G.H. e ao esforço em demonstrar sua ligação com o grupo cultural ashkenazi, o que não é necessário de se empreender no caso de Buber.

\section{1) A Paixão segundo G.H.: judaísmo, epifania, heresia e redenção}

Ao se relacionar A Paixão segundo G.H e judaísmo, primeiro deve-se refletir sobre como essa obra e a vida da autora se entrelaçam.

Nessa perspectiva, se em G.H. a experiência com a linguagem é levada ao indizível e conduz a um mal-estar nauseante, que abre caminho a uma realidade epifânica, dá para se ter uma ideia de como, em paralelo, o judaísmo lida com a palavra, ou melhor, com a ausência dela.

Segundo Berta Waldman, em "A retórica do silêncio em Clarice Lispector”, o silêncio fala na medida com que as pausas e o eco do dito ressoam, fazem refletir e criam reflexos de sentido sobre o que foi dito e sobre o que reverberou depois do dito. Clarice tinha consciência do limite da linguagem escrita e da frustração com o alcance das palavras, em traduzir a realidade, que escapa à apreensão da linguagem escrita, pois a compreensão advinda do silêncio, é maior que o que se consegue decodificar por meio da palavra.

Essa zona encoberta que lateja no texto e que está na origem da criação é referida em diferentes momentos da obra de Clarice Lispector [...] o silêncio é identificado como o desconhecido, como aquilo que ultrapassa aquele que enuncia, mas que ainda é ele, fazendo-se uma clara alusão tanto ao inconsciente, quanto a Deus, ambos amplamente mencionados na obra da autora, este, como o inominável e o intangível, o inconsciente como "aquele que não sabe", como o lugar dos "sonhos que são o modo mais profundo de olhar". [...] O silêncio, na obra de C. L. é tanto um tema com o qual seus personagens estão sempre às voltas, como uma atmosfera a marcar o espaço interno dessas mesmas personagens, como também algo que está no horizonte do processo de criação da autora. (WALDMAN, 2003, p. 5)

Segundo Waldman, Clarice busca o sentido no que "a palavra não alcança dizer, porque a palavra repousa sobre uma lacuna que oculta um vazio branco do qual, entretanto, ela depende". (ibid, p. 6)

É recorrente os personagens de Clarice abdicarem de pensamentos elaborados, de convenções, de pretensões intelectuais, justamente para se aproximarem do mais 
anticonvencional possível, em troca do que simplificaria o contato com esse núcleo duro da existência da vida. A tentativa de fundir presente, passado e futuro, que a autora denomina de instante já, ou presente remoto, ou neutro, funde sua própria condição humana à dos animais e da natureza, no que Waldman chama de "núcleo da existência". Essa fusão é alcançada, não via "pensamento organizado", mas por meio de uma "visão instantânea" desse núcleo. (ibid, p. 8).

A autora associa a obra de Clarice à obra Moisés e o Monoteísmo, de Freud, como na análise de Jean Lyotard a respeito, que observou que "a lei mosaica operou na cultura um retraimento do visível ao legível-audível" (ibid, p. 13). Ou seja, a proibição de representar por imagens o sagrado transferiu para a palavra falada e escrita a escuta de Deus, mesmo que essa escuta caia no abismo do silêncio, ou da consciência do limite da linguagem humana, que é apenas uma sombra imperfeita da voz silenciosa de Adonai. Pois, o que há de palpável, na verdade, é o silêncio. E é nele que se procura - mesmo sabendo que serão achados não mais que fragmentos - os vestígios do real. Como lembra Waldman, a tradição judaica na qual Clarice se insere é a do silêncio, a da ausência. Com isso, Lispector se vê numa eterna busca. Isso é tudo o que lhe resta e é ao que se agarra com todas as forças.

Um exemplo disso é a completa impossibilidade de se pronunciar o nome de Deus. Utiliza-se o termo Adonai, ou Senhor, demonstrando, mesmo nesse aspecto aparentemente simples, as implicações de uma concepção religiosa que compreende como intransponível a distância e a diferença do caráter existencial entre o Criador e a criatura, tamanha a complexidade da apreensão da realidade divina e da esfera do sagrado no judaísmo. "Segundo a cabala, o nome de Deus é todo o pentateuco, mas as letras estão embaralhadas", de acordo com Jorge Luis Borges (1987, p. 158), no livro Sete Noites, em que dedica um capítulo ao estudo desse tema. Cabala seria o conjunto de práticas esotéricas ou experiências místicas judaicas.

Outro dado do universo judaico que pode ser relacionado diz respeito ao Zohar, ou $O$ livro do esplendor. Nele, há a descrição das experiências místicas da cabala. O Zohar utilizado neste estudo é o organizado pelo rabino sefardita Ariel Bension, que selecionou trechos dos volumes da obra e trouxe, num único volume, compacto, as experiências místicas do judaísmo.

Nascido Juda Levi, em 1880 na cidade de Jerusalém, e morto em Paris, em 1932, a obra desse rabino é apresentada na introdução feita por Rosie Mehoudar, que oferece 
contribuições como a que segue abaixo, ao se referir ao fio condutor do rabino na obra. Bension seguiu as

ideias e trajetórias que lhe pareceram mais estruturais [...] e deu uma ordenação própria aos trechos que selecionou do original aramaico, agregando [...] algumas descrições. [...] De um modo geral, o Zohar é concebido como um comentário esotérico da Torá, em especial do Gênesis, incorporando citações e ideias da mística judaica posterior. A tradução de Bension confere um tom coloquial, não afetado e amoroso à relação entre o professor, protagonizado por rabi Shimon bem Yohai - um homem do século II-, e seus discípulos, que lhe fazem perguntas e ouvem suas exposições, sentados em campos da Galiléia. [...] O Zohar nos eleva a outros mundos, ao mesmo tempo os mais próximos de nós. (BENSION, 2014, pp. 16-18)

No Zohar, há a compreensão de que em tudo o que nos cerca há a presença da divindade. Haveria uma emanação universal, que, porém, deve ser buscada, desenvolvida. "O Zohar é a quintessência do desenvolvimento de muitas gerações de pensamento místico." (MEHOUDAR APUD BENSION, 2014, p. 55)

\footnotetext{
Apesar de o Zohar ter um estilo obscuro, onírico, não seria correto considerar o livro apenas uma casa de sonhos. Ele conservou centelhas de luz dos séculos futuros, no estilo do pensamento oriental, baseado na emoção e na intuição. Podemos também encontrar um toque de puro lirismo, ou alguma expressão que nos aproxima da natureza, mas iluminada e aprofundada para exprimir sensações que estão além do natural. (ibid, p. 58)
}

As semelhanças com a obra de Clarice estariam também na forma de se captar no cotidiano, questões não usuais, que passariam despercebidas pela maioria das pessoas, como que retirando películas superficiais de realidade e desnudando uma essência mais profunda que pode até ser sentida, mas que não é valorizada, ou considerada, que passa despercebida pela maioria. Essa camada mais subterrânea é desenterrada por ela e trazida à luz.

Pois encontramos centelhas de um fogo que está queimando em profundas cavernas ocultas para a visão humana; a possibilidade de viver para além do ordinário [...] mesmo em nossos contatos diários, para que nossa relação com o Infinito torne-se gradualmente mais clara e compreensível. O olhar é treinado para ver a vida e suas ações, o homem e suas experiências, de um ponto de vista diferente daquele a que estamos acostumados. (ibid, p. 59)

Quanto à relação entre a vida de Clarice e o judaísmo, seguem alguns dados biográficos. Filha de judeus ucranianos, crescida no Brasil, também tinha uma identidade cindida, por ser judia e, como ela mesma dizia, brasileira. Seguindo a tradição de seus pais, comum à comunidade judaica, ciente de suas origens e história diaspórica, Clarice, primeira geração de sua família a ser criada no Brasil, era acompanhada - a exemplo do que é 
abordado no Zohar sobre os judeus exilados - de três pilares da tradição religiosa judaica: a Torá, o Shabat e a língua hebraica, além do ídiche, língua materna de seus pais, irmãs e, provavelmente, a sua.

Curioso observar que, no Zohar, há referência a um panteísmo e unidade de todas as coisas, seres humanos, animais e natureza, semelhante ao que ela constrói, por exemplo, em G. H., em uma das passagens que descreve seu ritual epifânico, esvanecendo qualquer diferença entre sua existência e a da barata, assim como se diluem tempo e espaço, como no trecho a seguir:

Finalmente, meu amor, sucumbi. [...] Era finalmente agora. [...] Superficialmente como um quintal que é verde, da mais delicada superficialidade. Verde, verde - verde é o quintal. Entre mim e o verde, a água do ar. A verde água do ar. Vejo tudo através de um copo cheio. Nada se ouve. [...] Acordei de súbito do inesperado oásis verde onde por um momento eu me refugiara toda plena. Mas eu estava no deserto. E não é só no ápice de um oásis que é agora: agora também é no deserto, e pleno. [...] Eu talvez já soubesse que, a partir dos portões, não haveria diferença entre mim e a barata. Nem aos meus próprios olhos nem aos olhos do que é Deus. Foi assim que fui dando os primeiros passos no nada. Meus primeiros passos hesitantes em direção à vida, e abandonando a minha vida. O pé pisou no ar. E entrei no paraíso ou no inferno: no núcleo. [...] Com o jogo de feixes de luz, o teto se arredondara e transformara-se no que me lembrava uma abóbada. A vibração do calor era como vibração de um oratório cantado. Só minha parte auricular sentia. (LISPECTOR, 2009, p. 79-81)

A personagem se vê num feixe de sensações mescladas, pulsando num eterno agora, em uma espécie de êxtase, no qual se perceberia numa outra dimensão, não mais humana, mas sobrenatural, como que tomada pelo transcendente. Se vê unificada com uma atmosfera atemporal, fundida com a existência da barata, sua via de acesso à outra dimensão. O inseto de tempos imemoriais, signo de perenidade, de ausência de tempo e de sofrimento, é seu veículo de entrada, no caso, ao familiar presente remoto. A relação com o todo, fusão com a natureza e com as sensações extáticas, lhe conferem um estado meditativo, panteísta e sinestésico.

Outro dado em comum diz respeito à presença do componente erótico em diversas passagens do livro, ao se referir a rituais orgiásticos. No Zohar, esse teor herético é indiscutível.

Reina no Livro do Esplendor uma certa democracia do espírito que é singular. Por exemplo, vemos nas figuras místicas da Carruagem Divina espíritos de diferentes graus e formas de vida pássaros e animais e homens -, que estão em conflito uns com os outros no mundo ordinário, unidos na tarefa divina designada a elas, cooperando e complementando-se. Outro traço característico do misticismo do Zohar, que marca a influência que teve na sua geração e nas subsequentes, é a acentuada tendência ao uso de símbolos e expressões sensuais e eróticos, 
particularmente a união sexual, para designar verdades espirituais sublimes. [...] isto emana de um sistema que tende ao panteísmo e à unidade de todas as coisas. Tanto os símbolos quanto sua alma de unir-se com Deus e, através de Deus, com todas as coisas e perder-se completamente nessa união. (BENSION, 2014, p. 61)

Mais informações que esclarecem a respeito da cabala, para este estudo, provém do tomo I do Dicionário de Filosofia de José Ferrater Mora, no verbete homônimo. Nele, há a descrição de uma tradição que envolve reflexões sobre a Torá, sobre a tradição oral inserida na Mishná, sobre a liturgia, sobre a teurgia (a arte de fazer milagres e as superstições populares), sobre os anagramas (trocas de letras de palavras ou frases para formar outras, com novos significados), chegando os estudiosos da cabala a refletir sobre temas metafísicos.

O Zohar teria surgido na Espanha, no Século XIII. Nele, são tecidos comentários místicos sobre a Torá. Sua forma escrita foi apresentada pela primeira vez por Moisés de León, um rabino sefaradi. Nesse livro, Deus é considerado "uma realidade sem limite" e se manifestaria nos dez mandamentos e no Gênesis, por exemplo (MORA, 2001, p. 383).

Posteriormente, no século XVI, o estudo da cabala foi desenvolvido por Rabi Yitzchak Luria. Nascido em Jerusalém e criado no Egito, instalou-se posteriormente em Safed, Israel. Rabi Luria - ou ARI, como era conhecido - desenvolveu novo método de estudo da mística judaica, legando estudos como A Árvore da Vida, O Portal das Intenções e $O$ Portal das Reencarnações.

Após o surgimento do movimento hassídico no Século XVIII na região em que hoje é chamada Ucrânia, mais precisamente na Podólia, criado pelo Baal Schem Tov, ou Besht, nome pelo qual ficou famoso o Rabi Israel Ben Eliezer, houve a adaptação das experiências místicas da cabala, o que tornou esse conhecimento mais acessível, devido à criação e divulgação de lendas devocionais.

Internamente, o movimento era baseado na tradição doutrinária da cabala e, externamente, na prática da vida cotidiana, baseava-se no êxtase, serviço, busca da redenção e humildade. No verbete "Mística" do referido dicionário filosófico de Mora, há um trecho em que se comenta sobre o significado dado a essa palavra por Ludwig Wittgenstein, complementando a compreensão sobre o fenômeno.

O termo mística estaria associado ao que é indizível, que deve ser silenciado, tamanho o mistério, que não caberia na explicação dada por palavras. O filósofo também entende que se não se pode traduzir em palavras, deve-se silenciar, pois, o indizível falaria por si mesmo. Essas experiências místicas seriam inexprimíveis, apenas experienciáveis. Numa 
escalada de argumentos para se entender o fenômeno associando-o à linguagem, esta careceria de sentido, ou mesmo que se aproxime dele, é metamorfósica, fugidia e subjetiva, não passível de apreensão objetiva (MORA, 2001, p. 1977).

Tal como nesse universo da mística judaica a literatura clariceana é marcada por esse sentido de que fala Wittgenstein: a natureza de sua linguagem é igualmente metamorfósica, fugidia e subjetiva, não afeita à apreensão objetiva; seus temas dizem respeito ao indizível, ao que deve ser silenciado, ou ao que deve falar pelo silêncio.

Em decorrência dessa incomunicabilidade da mística, o Zohar é de difícil compreensão para os não-iniciados, pois geralmente é estudado apenas por estudiosos da Torá. Escrito tradicionalmente em hebraico e aramaico, traz imagens simbólicas, usadas no lugar de terminologia usual. Tópicos independentes são tratados em conjunto, colocando lado a lado assuntos aparentemente sem relação entre si. Na verdade, as conexões são claras para os que entendem seu simbolismo e significado. O Zohar descreve uma realidade esotérica escondida na vida cotidiana. Temas, histórias e assuntos litúrgicos são percebidos por meio de uma interpretação mística, coincidindo com a linguagem da narrativa clariceana, como em G.H., por exemplo.

Pela perspectiva de uma linguagem incomum, que consagra o silêncio e permeada por percepções que fundem personagem, natureza, espaço, cosmos, sensações, busca por redenção, sentido e apaziguamento de angústias, G.H. espelharia a cosmovisão cultural judaica e, em específico, a proveniente de experiências místicas.

De acordo com Bella Jozef, em "Clarice Lispector, a quarta dimensão da palavra", devese ler Clarice como a escritora lia o mundo, numa visão incomum sobre o eu e o cosmos. Lembrando que a autora enxergava o mundo com o olhar de alguém que proveio de um ambiente judaico, de família e educação ashkenazi, do leste europeu.

Para se entender um pouco sobre o significado do termo ashkenazi, segue uma breve apresentação histórica a respeito.

O ramo cultural/geográfico/étnico ashkenazi, compreende o contingente humano proveniente da Europa ocidental, central e oriental, de descendentes de judeus francoalemães. O termo surgiu na Idade Média, e em sua origem, designava os judeus de origem alemã, mas devido à origem comum a todos eles, ou seja, serem todos descendentes de judeus franco-alemães, o termo passou a designá-los enquanto grupo unificado, mesmo não sendo homogêneo. Esso extenso grupo cultural, engloba a utilização de diferentes dialetos do ídiche (espécie de mistura entre o hebraico e o alemão), certa variedade de rituais, liturgias, projetos arquitetônicos de sinagogas, métodos de estudo e pronúncia do 
hebraico; o que os distingue do outro grande grupo cultural/geográfico/étnico judaico, o dos sefarditas, judeus provenientes da Península Ibérica e do norte da África, que tem como língua, o ladino (uma espécie de mistura entre o hebraico e o espanhol), além de diferenciações, em relação aos demais elementos acima apontados.

Publicações como por exemplo, o Livro dos Devotos, ou o Sefer Chassidim, publicado no Século XVI, - apesar de ter sido escrito no Século XIII, por Judá Há-Chassid, um místico e líder petista alemão, conhecido como fundador de um movimento denominado Chassidei Ashkenaz, que inseriu um componente ascético na vida judaica da comunidade -, foi adotado pela comunidade de judeus da Europa ocidental, central e oriental, o que favoreceu uma maior homogeneidade cultural e doutrinária ao grupo, além de fortalecer a ideia de uma identidade mais unificada, aproximando seus integrantes e favorecendo o desenvolvimento de uma espécie de "cimento" cultural específico, particular, dos assim chamados ashkenazi.

O Livro dos Devotos ou Sefer Chassidim retrata a cultura pietista, proveniente de um tipo específico de devoto, o devoto hassídico. Essa cultura foi o fator responsável por essa maior aproximação identitária. A influência do Sefer Chassidim se manteve intacta até o advento da modernidade.

Outro dado expressivo dessa identidade específica judaica, diz respeito à personagens históricos da comunidade ashkenazi, como Gershom, ou Rabenu, que viveu entre os Séculos X-XI da Era Cristã e que também fortaleceu a ideia de uma identidade comum ao grupo, pois esse personagem histórico, Gershom, foi líder de uma ieshivá (centro de estudos de textos religiosos, como o Talmud e a Torá) na Mogúncia, ou Mainz, uma cidade alemã que atraiu estudantes desses textos sagrados, de toda a Europa, tendo sido Gershom considerado o pai espiritual da comunidade ashkenazi.

Por fim, o shtetl, cidadezinha, ou aldeia, era uma pequena comunidade de judeus da Europa oriental medieval, muito comum na Rússia, Ucrânia, Polônia e Lituânia, além da parte leste do Império Austro-Húngaro. "O shtetl foi o principal centro demográfico dos ashkenazim do século XIX, e sua língua franca era o ídiche, que os judeus chamavam de a "língua mãe". (UNTERMAN, 1992, p. 246)

Parte da literatura de Clarice, em especial A paixão segundo G.H., integraria de forma implícita, essa trajetória cultural. Tanto ela, quanto Martin Buber, fariam parte dessa mesma história.

Em G.H., esses elementos são encontrados na narração de uma experiência mística, metafísica e epifânica, descrevendo o contato com o Absoluto, baseado em uma busca 
pela eternidade. A personagem procura despir-se de sua condição humana ao tentar desvencilhar-se de convenções sociais estabelecidas e do contexto da realidade circundante.

São utilizados termos como elemento neutro e desorganizar, desmontando o cenário em que se encontra a actante, que é o quarto de sua empregada, num apartamento suburbano. A escritora também desorganiza a realidade factual quando aproxima a existência de um ser humano adulto, G.H., a de um inseto, no caso, uma barata.

O contato entre a personagem e a barata é surpreendente. Assim, ela iguala a existência humana à do inseto, abolindo diferenças existenciais, apenas lhes conferindo uma mesma ordem de contato, numa espécie de sintonia concretizada por uma inaudita alteridade. Novamente a fusão com o todo.

$\mathrm{Na}$ obra, a personagem racionaliza e questiona sua própria compreensão do que seja a realidade. Postula uma espécie de "dissolução" de si mesma, acusando a si de ter humanizado demais a própria vida (LISPECTOR, 2009, p. 12). Faz elucubrações sobre o sentido das coisas, das convenções humanas e sociais, dos limites entre o ser humano, os objetos, os animais, o espaço, o tempo, como que unificando toda a percepção da existência e da realidade, reinventando-as. Assim, G.H. considera a possibilidade de acatar o "assassinato de minha alma humana". (ibid, p. 14)

É recorrente a utilização de termos de um mesmo universo lexical - como ritual, vida, morte, Deus, sacrifício, organização, desorganização, despersonalização, culpa, medo, orgia, demoníaco, redenção, estado de graça, sagrado, libertação, sangue, abismo, nada, preocupações cosmogônicas, salvação, o indizível, paraíso, inferno, deserto, caverna, lei, reino. Uma atmosfera mística e epifânica se estabelece, em seu mergulho na narrativa de um tempo psicológico e de um monólogo interior.

Clarice usa imagens como caverna, deserto e eternidade, num turbilhão de experiências na narrativa que mergulha no universo psicológico da protagonista, em um tempo que para, em um espaço não palpável, volátil, que mais lembra uma miragem no deserto pleno de significados e de imagens incríveis.

Dilui-se tempo, espaço e personagem. Em dado momento, o espaço do apartamento transforma-se em uma caverna, com salões naturais, pois, o espaço referido é simbólico e anterior ao homem. Dessa feita, os elementos espaciais em Lispector (um quarto de empregada, um apartamento citadino, o fundo dos prédios, as áreas de serviço) desempenham uma função ativa na trama, pois são eles que dão vazão a uma experiência maior: o quartinho no fundo do apartamento, por onde entra um sol de corroer as vistas, 
é o gatilho para que viajemos, junto com G.H., a um tempo não preso a limites geográficos, ou circunscrito a paredes. O quarto será ultrapassado, superado: por ele chegaremos à caverna, transcendendo as cidades e a própria atualidade do homem.

Trechos transgressores ou heréticos presentes na narrativa não reduzem o aspecto religioso do texto. A barata é escolhida por ser um inseto que remete à origem do mundo e por ter, assim, o componente de eternidade, pois, no caso de um apocalipse ou desastre atômico, somente ela sobrevive. Atrai G.H. o fato de o inseto habitar e caminhar no subterrâneo, no escuro, em meio a frestas, assim como sua reprodução em profusão e que corresponderia ao que ela chama de matéria da vida, vida, mundo. (ibid, p. 123)

Ao ingerir a barata, a personagem se vê transformada no ventre do mundo. É mãe do mundo, num sentimento de proteção e compaixão. A autora associa a eternidade da barata ao infinito. Iconoclasta e transgressora, ela lança mão de artifícios de confronto com a divindade, com o Absoluto, com o incomensurável, para atingir a redenção e se aproximar de Deus, seu real objetivo e fim, pois, admite que:

no neutro do amor está uma alegria contínua, como um barulho de folhas ao vento. [...] O mesmo neutro, aquele que me havia consumido em perniciosa e ávida alegria, era nesse mesmo neutro que eu agora ouvia outra espécie de alegria contínua de amor. O que é Deus estava mais no barulho neutro das folhas ao vento que na minha antiga prece humana. [...] A menos que eu pudesse fazer a prece verdadeira, e eu aos outros e a mim mesma pareceria a cabala de uma magia negra, um murmúrio neutro. Esse murmúrio, sem nenhum sentido humano, seria a minha identidade tocando na identidade das coisas. Sei que, em relação ao humano, essa prece neutra seria uma monstruosidade. Mas em relação ao que é Deus, seria: ser. Eu fora obrigada a entrar no deserto para saber com horror que o deserto é vivo, para saber que uma barata é a vida. Havia recuado até saber que em mim a vida mais profunda é antes do humano - e para isso eu tivera a coragem diabólica de largar os sentimentos. Eu tivera que não dar valor humano à vida para poder entender a largueza, muito mais que humana, do Deus. Havia eu pedido a coisa mais perigosa e proibida? Arriscando a minha alma, teria eu ousadamente exigido ver Deus? E agora eu estava como diante Dele e não entendia - estava inutilmente de pé diante Dele, e era de novo diante do nada. [...] E vendera a minha alma para saber. Mas agora eu entendia que não a vendera ao demônio, mas muito [...] a Deus. Que me deixaria ver. Pois Ele sabia que eu não saberia ver o que visse: a explicação de um enigma é a repetição do enigma. O que És? E a resposta é: És. O que existes? E a resposta é: o que existes. Eu tinha a capacidade da pergunta, mas não a de ouvir a resposta. (ibid, pp. 133-134).

Com o trecho final da citação acima reproduzida, a personagem se rende à tradição das sucessivas interpretações dos sentidos das narrativas dos textos sagrados, no exercício de ressignificação, que busca se aproximar das verdades sagradas, mesmo se sabendo fugidias e infinitamente distantes da condição humana, pois inatingíveis em sua natureza atemporal, guardiã de verdades ancestrais, interditas à inteligência dos seres humanos. A relação ancestral com o sagrado, é transmutada na literatura, de maneira a lhe conferir maior eficácia formal. Tal transgressão, porém, não rompe o liame com sua tradição mística, só se reveste de roupagem afeita à sua contemporaneidade. 
A experiência do cotidiano, transformada em experiência epifânica, enquanto componente herético, é recorrente à literatura judaica, como lembra Luis Sérgio Krausz, em Santuários Heterodoxos, pois, a mesma faz parte de uma identidade específica que se edifica.

cultura literária judaica laica, autônoma, anticlerical, e em certa medida, herética - um processo que se dará a meio caminho entre a tradição e a modernidade, entre o mundo do gueto e o desvario moderno, em meio ao qual surge este personagem de singular importância não só na literatura judaica, mas na literatura ocidental de um modo geral: o judeu moderno. O romance de estranhamento, da heresia, da revolta [...] é, portanto, o que melhor se ajusta à emergência desta subjetividade literária e deste personagem, o judeu moderno, que se torna tanto quanto mais ubíquo quanto mais avança o processo de emancipação judaica e de integração mais ou menos bem sucedida dos judeus às sociedades europeias. (KRAUSZ, 2017, p. 16)

Apesar das diferenças geográficas e cronológicas, a literatura judaica a qual o autor se refere abarca uma enormidade de produção e espaço que engloba o período entre os Séculos XVIII e XX, e, independente de Clarice ter crescido no Brasil, seu nascimento, família, origem e criação, como anteriormente referido, patentearam sua visão de realidade e sua relação com os enfrentamentos da vida. Não se deve esquecer que Clarice lutou para ter reconhecido o direito de ser considerada brasileira, além de ter se naturalizado brasileira, ter se casado com um brasileiro católico e, logo, lutado para ser assimilada numa sociedade e cultura que, apesar de terem lhe influenciado, não apagaram suas referências primeiras.

A cultura ashkenazi teria sido o maior fator amalgamador, gerador de uma cosmovisão identitária comum a essa tradição, dentro do judaísmo, do que os fatores geográficos. Daí ser plausível a inserção de Clarice e de sua obra, nesse grupo, apesar de ela ter escrito em português.

De acordo com Benjamin Moser em Clarice, uma biografia, haveria fortes indícios da influência da cultura hassídica sobre Clarice.

Clarice, ainda emanaria uma espécie de energia mística, que atraía como um imã, os que a conheciam, ela exalaria um mistério que, segundo os que lhe viram pessoalmente, era de difícil definição (MOSER, 2017). A literatura imaterial da autora, dava testemunho de sua ligação com o sublime e o divino.

Em um trecho do livro, o crítico estadunidense cita Gershom Scholem, em Grandes Correntes da Mística Judaica, no inglês Major Trends in jewish Mysticism, em edição de 1995, das páginas 337 a 338, ao fazer as seguintes indagações: 
Pode um lugar imprimir seus traços em alguém que o abandonou no início da infância? Aparentemente não. No entanto permanece o fato de uma grande mística ter nascido num lugar famoso por seus grandes místicos. Talvez o fato mais notável acerca da região de onde veio Clarice Lispector não fosse a pobreza nem a opressão, mas sua elétrica relação com o divino. Isolados e pobres, os judeus da Podólia eram frequentemente arrebatados por ondas milenaristas. [...] Tamanho era o fascínio da misteriosa figura de Clarice Lispector, e tão pouco o que se sabia sobre suas origens, que ainda durante sua vida todo um conjunto de lendas floresceu em torno dela. Nisso ela se assemelhava aos santos judeus de sua terra natal, os tzadikim hassídicos, "portadores daquela coisa irracional", figuras míticas em seu próprio tempo, sobre os quais "uma transbordante abundância de histórias", misturava indissoluvelmente "trivialidade e profundidade, ideias tradicionais ou emprestadas e verdadeira originalidade". (MOSER, 2001, pp. 33-34)

Essa espécie de enigma, no qual irradiava a personalidade de Chaya, seria uma amostra da existência hassídica, que orienta uma vivência de contínua manifestação de êxtase divino, envolvendo criaturas e objetos, tocados por uma irradiação de natureza não humana, mas transcendental.

Sobre a insuficiência com a linguagem, descreve o alcance possível do indizível:

É exatamente através do malogro da voz que se vai pela primeira vez ouvir a própria mudez e a dos outros e a das coisas, e aceitá-la como a possível linguagem. [...] Eu tenho à medida que designo - e este é o esplendor de se ter uma linguagem. Mas eu tenho muito mais à medida que não consigo designar. [...] A linguagem é meu esforço humano. Por destino tenho que buscar e por destino volto com as mãos vazias. Mas - volto com o indizível. O indizível só me poderá ser dado através do fracasso e minha linguagem. Só quando falha a construção é que obtenho o que ela não conseguiu. [...] A trajetória somos nós mesmos. (LISPECTOR, 2009, p. 175-176)

Com a leitura dessa passagem acima citada, pode-se perceber que a personagem se compara a "um dos espasmos instantâneos do mundo" (ibid, p. 178), numa simbiose que constrói entre a personagem e tudo que a cerca, objetos, pessoas, animais e natureza. $\mathrm{O}$ que coincide com a identificação entre um rabino, os animais e a natureza circundante, em um conto denominado "A linguagem dos pássaros", um dos contos transcritos por Martin Buber, originários de lendas orais hassídicas, e veículo de aproximação com G.H., o que será apresentado na próxima seção deste estudo.

\section{2) Conexões entre A paixão segundo G.H., A lenda do Baal Schem e As histórias do}

\section{Rabi Nakhman, de Martin Buber}

O livro de contos sobre os ensinamentos e experiências do Baal Schem Tov - ou Rabi Israel Ben Eliezer, o Mestre do Bom Nome - retrata um pouco da vida do fundador do movimento hassídico. De autoria de Martin Mordechai Buber, judeu austríaco, nascido em 8 de fevereiro de 1878 em Viena, a obra apresenta antes dos contos propriamente ditos, 
as principais características do movimento, que seriam o fervor do êxtase, ou hitlahavut; o serviço, ou a avodá; a finalidade da redenção ou kavaná e a humildade, ou schiflut.

Segundo Buber,

No êxtase tudo o que é passado e o que é futuro se aproxima do presente. O tempo encolhe, a linha entre as eternidades desaparece, só o momento vive e o momento é eterno. Em sua luz indivisa aparece tudo o que era e tudo o que será, simples e composto. (BUBER, 2003, p. 25)

A origem cultural e afetiva na qual Clarice se insere marca a sua narrativa, em especial em G.H. Nascida Chaya Pinkhasovna Lispector, em 10 de dezembro de 1920, em Chechelnyk (Ucrânia), num schtetl, ou cidadezinha, uma:

comunidade segregada [...] localidade rural, ilhota quase exclusivamente judaica em meio ao mar eslavo, era a base de uma sociedade sui generis, misto de classe social, minoria nacional e congregação religiosa. Composta em sua esmagadora maioria de pequenos mercadores, artesãos, estalajadeiros, contratadores e arrendatários [...] e vinculava-se interiormente, não só pelo tronco e pelas tradições de Israel, como por um passado local de vários séculos, por uma língua específica e a clara consciência de um destino comum [...] aos olhos do judeu do schtetl, social e psicologicamente alheio ao utilitarismo ocidental, justificava "este" mundo: a esfera edênica da beatitude sabática, o outro mundo [...] Era aí, neste reino, que [...] trocava de "alma", se revestia dos parâmetros da "infinita devoção", ingressava na santa congregação dos eleitos, colocava-se diretamente em face do Trono de Glória, colhendo sua luz com os olhos da fé. Neste mundo "intoxicado e Deus", nada mais separava a criatura de seu Criador. (GUINZBURG, 1971, pp. 4447)

As origens culturais e geográficas de Chaya coincidem com a visão descrita por Buber no referido livro de contos:

aquele que deseja [...] abraçar Deus o vê em todas as coisas do mundo apenas a força e o orgulho do Criador do começo dos começos que vive nelas. Mas, aquele que não está neste patamar vê as coisas separadas de Deus. [...] Ela amplia a alma até o todo. [...] A criação do céu e da terra é o desdobramento do algo a partir do nada, a descida do mais alto até o mais baixo. (BUBER, 2003, pp. 27).

Diante do acima exposto, nas referências à Guinzburg e à Buber, pode-se esclarecer uma pouco mais sobre o contexto cultural e religioso do hassidismo.

Em outra passagem retirada do livro de Buber, há a afirmação de que "O mistério da graça não é sujeito à interpretação" (BUBER, 2003, p. 30). Segundo o ensinamento hassídico pelo autor destacado, "cada pessoa só pode atuar em seu domínio. Cada qual tem, no espaço e no tempo, uma esfera de existência específica que lhe foi concedida para ser redimida por meio dele". (BUBER, 2003, p. 39) 
Aquele que conhece a melodia secreta que transporta o interior para o exterior, que conhece a sagrada ciranda que amalgama as palavras solitárias e tímidas no cântico dos longes está pleno da força de Deus, e "é como se criasse céu e terra e todos os mundos de novo". Ele não encontra diante de si o seu reino como sucede ao libertador das almas, ele o estende do firmamento às profundezas silenciosas. Mas também ele atua para a redenção. [...] Assim a criatura atuante prepara a União Final do Todo. [...] criar significa ser criado: o divino se move e nos subjuga. E ser criado é êxtase: somente aquele que imerge no Nada do Incondicionado recebe a mão modeladora do espírito. (BUBER, 2003, pp. 41-42)

Em "A linguagem dos pássaros", Buber transcreve uma lenda hassídica que retrata a busca de um rabino pela compreensão absoluta dos sons emitidos pela natureza. No caso, os sons emitidos pelos animais, vertebrados e invertebrados, animais selvagens, rastejantes e até os que vivem sob a terra, seriam por ele entendidos. Para tanto, procura os ensinamentos do Baal Schem Tov, que se prontifica a lhe transmitir a devida sabedoria, desde que fosse de seu merecimento e estivesse à altura de tamanha tarefa.

No momento em que estavam em uma carruagem em movimento, em meio a um bosque, ao invés de o rabino ouvir atentamente as palavras do Baal Schem Tov, ficou dividido entre a maravilha de entender as vozes da natureza e os conselhos do Baal Schem. Nesse instante, foi por este interpelado e não mais conseguiu entender os significados do que voltou a ser sons sem sentido para ele.

Nessa lenda, verifica-se também uma aproximação entre o humano e, no caso, os animais, numa ausência de fronteiras e diferenciações existenciais, como se ambas as condições fizessem parte de um só cosmos pleno de sentido, graças às características do pietismo hassídico e à consciência de uma unidade proveniente de uma só Criação.

Para Buber, apresentar ao mundo o teor das lendas hassídicas era apresentar uma "genuína experiência metafísica da unidade primal do mundo, a qual [...], a reinante civilização burguesa com seu ethos divisório e intelecto analítico havia ofuscado". (MENDESFLOHR; GRIES, 2000, p. 14)

$\mathrm{Na}$ introdução do livro de Buber, As histórias do Rabi Nakhman, Mendes-Flohr e Gries lembram que Buber defendia corajosamente, - pois muito criticado e desacreditado no início e seus estudos -, que o hassidismo é baseado em uma "apreensão da unidade primordial do mundo”. (MENDES-FLOHR; GRIES, 2000, p. 15). Afirmação ousada, diante de uma noção difusa de que a religião mosaica seria desprovida de "espontaneidade e espiritualidade" (ibid). Buber confrontou um preconceito predominate, devido à incredulidade acerca de suas descobertas, investigando e divulgando não só as lendas hassídicas associadas ao Baal Schem Tov, como também lendas e a biografia de um outro 
rabino famoso no seio da comunidade hassídica, o Rabi Nakhman de Bratzlav, provavelmente o "último místico judeu". (ibid)

Nesse livro, Buber, relata a vida do Rabi Nakhman, bisneto do Baal Schem, em sua procura pelo sagrado. Nakhman nasceu em 1772, em Mesbistz, na Ucrânia, a mesma cidade de seu bisavô, e morreu em 1810, em Uman, também Ucrânia.

A exemplo de G.H., guardadas as diferentes trajetórias, pode-se apreender o contato com o absoluto, em que se apaziguam as angústias, junto à natureza, na integração panteísta que reúne o cosmos e o dota de sentido.

A infância do Rabino, suas experiências pessoais de encontro epifânico, expressam êxtase semelhante ao de G.H., ao, por exemplo, em determinado ponto de sua vida, ter se mudado para o campo e ter se sentido integrado à natureza, de uma forma por ele considerada divina. Sua relação com o sagrado também mergulha no panteísmo e em experiências meditativas.

Acostumado ao confinamento da cidade, ao se ver em meio à natureza, sua alma se sentiu livre, pois

agora, como num reino mágico, em vez do amarelo desbotado das paredes das ruas, o verdor florestal e as floradas dos bosques o envolviam, os muros de seu gueto espiritual vieram abaixo de repente, ao contato com as força das coisas em crescimento". (BUBER, 2000, p. 41)

Buber observa que o Rabi Nakhman "alegre e facilmente encontrava seu Deus em todas as coisas", pois

Deus [...] o olhava de todas as árvores e com quem cada planta estava em íntima relação. [...] Quando o homem se torna digno [...] de ouvir os cânticos das plantas, com cada uma delas profere seu canto a Deus, quão belo e doce é ouvir seus cantares! [...] Em cada alento você se abebera no ar do paraíso, e quanto você volta para casa o mundo está renovado a seus olhos. O amor ardente por tudo que está vivo e cresce era forte nele. (BUBER, 2000, p. 42)

Rabi Nakhman continuou a tradição de difundir a cabala não apenas por meio do Zohar, mas por meio de lendas místicas exemplares, em um movimento de transmissão de pessoa a pessoa, de geração a geração. Ele dedicou sua vida à sua comunidade, foi à Jerusalém, mas retornou para seu povo. Morou em Bratislava, hoje capital da Eslováquia, tendo voltado de Jerusalém ainda mais inebriado pelo sagrado.

No final de sua vida, decidiu se mudar para Uman, Ucrânia, para poder ser enterrado junto do local onde estavam sepultados todos os judeus assassinados de uma só vez, por um bando de ucranianos, pouco antes de seu nascimento. Ele acreditava que fazendo isso, 
libertaria as almas dos mortos, que estariam presas no lugar em que foram enterrados seus respectivos corpos.

É um movimento semelhante, mesmo que de diferentes proporções, ao que Krauz observa sobre obras literárias de judeus ashkenazi dos Séculos XVIII e XIX, que, independente do período, país e idioma, "são perpassadas pelas perplexidades e dúvidas desencadeadas por um movimento de afastamento em relação aos valores e conceitos próprios do judaísmo tradicional" (KRAUZ, 2017, p. 253). Haveria uma espécie de continuidade da visão cultural independente da geografia e data de nascimento dos autores, pois, o que se sobrepõe é a base cultural judaica ashkenazi e, em particular, a cultura hassídica.

\section{Considerações Finais}

No decorrer do presente texto, foi possível observar afinidades entre A paixão segundo G.H., de Clarice Lispector, o conto "A linguagem dos pássaros", do livro A lenda do Baal Schem e trechos do livro As histórias do Rabi Nakhman, de Martin Buber, devido a uma base cultural comum que referenciou a percepção de realidade dos dois autores relacionados. O encantamento cotidiano, advindo do núcleo hassídico, exerceu sua influência nas referidas obras, pois, apesar das diferenças de suas propostas, - do intervalo temporal e da distância geográfica, - a cosmovisão ashkenazi é o que prevalece entre os escritos dos autores.

Em Clarice, tanto a devoção cotidiana hassídica encontra-se na entrega à experiência epifânica do sagrado em G.H. para se atingir a redenção, em meio às descrições em que a personagem mergulha na busca por si mesma e pela ressignificação de sua existência, que, para ascender, desce nas profundezas da deseroização, do desmantelamento das convenções humanas e no limite máximo da desorganização de si e da linguagem, para, então, retornar ao cotidiano "normalizado" após tamanha transição existencial e mística. Não obstante as diferenças, o encantamento no cotidiano, o panteísmo, a epifania e a presença das características devocionais hassídicas nas três obras atestam sua conexão cultural indelével, de mesmo horizonte de sentido.

\section{Referências}

BENSION, A. O Zohar: o livro do Esplendor. Passagens selecionadas pelo rabino Ariel Bension (1880-1932). Prólogo de Miguel de Unamumo. 5a ed. Trad. e introdução, Rosie Mehoudar; Rita Galvão. São Paulo: Polar, 2006.

BORGES, J. L. Sete Noites. Trad. João Silvério Trevisan. $4^{a}$ ed. São Paulo: Max Limonad, 1987. 
BUBER, M. As histórias do Rabi Nakhman. Tradução de Fany Kon e J. Guinsburg. São Paulo: Perspectiva, 2000.

Perspectiva, 2003.

A lenda do Baal Schem. Trad. Fany Kon E J. Guinsburg. São Paulo: Ed.

GUINZBURG, J.; FALBEL, N. (Org.). Aspectos do hassidismo. São Paulo: Editora B'Nai B'Rith, 1971.

KRAUSZ, L.S. Santuários heterodoxos. Subjetividade e heresia na literatura judaica da Europa Central. São Paulo: Edusp, 2017.

LISPECTOR, C. A paixão segundo G.H. Rio de Janeiro: Rocco, 2009.

MENDES-FLOHR, P; GRIES, Z. In: BUBER, M. As histórias do Rabi

Nakhman. Tradução de Fany Kon e J. Guinsburg. São Paulo: Perspectiva, 2000.

MOSER, Benjamin. Clarice, uma biografia. Trad. José Geraldo Couto. São

Paulo: Cosac Naify, 2011.

MORA. J. F. Dicionário de Filosofia. Tomo I (A-D). São Paulo: Loyola, 2001.

. Dicionário de Filosofia. Tomo III (K-P). São Paulo: Loyola, 2001.

UNTERMAN, A. Dicionário Judaico de lendas e tradições. Trad. Paulo Geiger.

Rio de Janeiro: Jorge Zahar, 1992.

WALDMAN, B. A retórica do silêncio em Clarice Lispector. In: WALDMAN, Berta. Entre passos e rastros: presença judaica na literatura brasileira contemporânea. São Paulo: Perspectivas. FAPESP. Associação Universitária de Cultura Judaica, 2003.

\title{
CONNECTIONS OF MEANING: THE ASHKENAZIC LITERATURE IN THE PASSION ACCORDING TO G.H., WRITTEN BY CLARICE LISPECTOR, IN THE SHORT STORY “THE LANGUAGE OF THE BIRDS", AND THE BOOK THE STORIES OF RABI NAKHMAN, BY MARTIN BUBER
}

\begin{abstract}
When read together, the epiphanic experience of The passion according to G.H. and the Hassidic tales, such as the short story The Language of the Birds from the books The Legend of Baal-Shem and The stories of Rabbi Nakhman, written by Martin Buber, certifies the Ashkenazic Judaic cosmovision present in these works. Contributions from relevant critique and readings regarding the Judaic mysticism demonstrate approximation between both of them as they portray a daily life of enchantment, sacralization and devotion.
\end{abstract}

Keywords

Clarice Lispector. The Passion According to G.H.. Martin Buber. Hassidic tales. Rabi Nakhman. 